Running Head: POLARIZING NEWS

Polarizing News? Representations of Threat and Efficacy in Leading U.S. Newspapers' Coverage of Climate Change

\author{
Lauren Feldman \\ Rutgers University \\ P. Sol Hart \\ University of Michigan \\ Tijana Milosevic \\ University of Oslo
}

Corresponding Author ${ }^{1}$

Author Biographies ${ }^{2}$

Funding Acknowledgement ${ }^{3}$

\footnotetext{
${ }^{1}$ Lauren Feldman, Rutgers University, School of Communication \& Information, 4 Huntington Street, New Brunswick, NJ 08901. Email: lauren.feldman@rutgers.edu

${ }^{2}$ Lauren Feldman is an assistant professor in the School of Communication and Information at Rutgers University. Her research focuses on political communication, science communication, and media effects. P. Sol Hart is an assistant professor in Communication Studies and the Program in the Environment at the University of Michigan. Dr. Hart specializes in environmental, science, and risk communication. Tijana Milosevic is a postdoctoral researcher in children and media at the University of Oslo. She completed her doctoral dissertation titled "Cyberbullying Policies of Social Media Companies: Towards Digital Dignity" at American University, and her research focuses on children and media and social media policy. 3 This study was supported by the National Science Foundation (SES-1419604).
} 


\begin{abstract}
This study examines non-editorial news coverage in leading U.S. newspapers as a source of ideological differences on climate change. A quantitative content analysis compared how the threat of climate change and efficacy for actions to address it were represented in climate change coverage across The New York Times, The Wall Street Journal, The Washington Post, and USA Today between 2006 and 2011. Results show that The Wall Street Journal was least likely to discuss the impacts of and threat posed by climate change, and most likely to include negative efficacy information and use conflict and negative economic framing when discussing actions to address climate change. The inclusion of positive efficacy information was similar across newspapers. Also, across all newspapers, climate impacts and actions to address climate change were more likely to be discussed separately than together in the same article. Implications for public engagement and ideological polarization are discussed.
\end{abstract}




\section{Polarizing News? Representations of Threat and Efficacy in Leading U.S. Newspapers' Coverage of Climate Change}

The global scientific community is in widespread agreement that climate change is occurring and that the majority of observed warming in the climate system is due to human activities (IPCC, 2013). In the U.S., recent reports indicate that climate impacts are already being felt across the country (Melillo, Richmond, \& Yohe, 2014; Romero-Lankao et al., 2014); however, public opinion remains divided on the issue. These divisions increasingly fall along ideological lines, with liberals more accepting of and concerned about climate change than conservatives (McCright \& Dunlap, 2011). Various explanations have been advanced to account for this polarization, prominent among them the media's conflicting information flows on the issue (McCright \& Dunlap, 2011). In a high-choice media environment that facilitates selective exposure to like-minded news, distinct cues about climate change can polarize attitudes of opposing partisans (Feldman, Myers, Hmielowski, \& Leiserowitz, 2014). Scholars interested in how representations of climate change vary across U.S. media outlets primarily have focused on cable news organizations (e.g., Feldman, Maibach, Roser-Renouf, \& Leiserowitz, 2011), such as MSNBC and Fox News, which are well known for their respective liberal and conservative orientations. However, these outlets tend to attract a relatively narrow audience of strong partisans (Levendusky, 2013) and therefore may not fully account for the media's effects on opinion polarization among the broader U.S. population.

Thus, this study instead focuses on representations of climate change in the straight news coverage of leading U.S. newspapers, including The New York Times, The Wall Street Journal, The Washington Post, and USA Today. In addition to these newspapers being among the nation's most read (Alliance for Audited Media, 2013), they differ from one another in the political slant 
of their coverage and the partisan composition of their audiences (e.g. Gentzkow \& Shapiro, 2010, 2011; Groseclose \& Milyo, 2005). This suggests that there may be disparities in their reporting on climate change, with implications for the ideological divides in U.S. public opinion. Although climate change coverage in U.S. newspapers has been widely studied (e.g., Boykoff \& Boykoff, 2004; Boykoff, 2007a), the potential for differences between newspapers, particularly in non-editorial coverage, has received scant attention, a gap this study helps to fill.

This study also advances a novel framework for analyzing representations of climate change in the press. Prior analyses of climate change coverage in U.S. newspapers have focused on claims of scientific uncertainty. For example, Boykoff and Boykoff (2004) found that between 1988 and 2002, the U.S. prestige press - which includes the newspapers we study here diverged significantly from the scientific view on climate change by giving equal attention to a small group of skeptics who questioned human contributions to global warming. However, by 2005, evidence for this false balance largely disappeared (Boykoff, 2007a; Nisbet, 2011). Thus, in the current study, which evaluates newspaper coverage between 2006 and 2011, we move away from analyzing claims of uncertainty about climate science and instead analyze how information about the threat of climate change and efficacy for actions to address it is communicated. Using content analysis, we examine threat and efficacy information both directly and indirectly, through the discussion and framing of climate change impacts and actions. To our knowledge, this is the first study to analyze representations of threat and efficacy in climate change news reporting in the U.S. prestige press.

The current study builds on prior research (Authors, 2014), which analyzed the representation of threat and efficacy in U.S. network TV news coverage of climate change. By extending this work to newspapers, we can assess the generalizability of our earlier findings 
across U.S. media channels and, importantly, evaluate whether representations of threat and efficacy vary between newspaper outlets in a way that reflects ideological polarization on climate change. The results indicate that representations of threat and efficacy indeed serve as sources of ideological differences in climate change coverage across news outlets. Moreover, the results signify that systematic differences in U.S. media coverage of climate change are not restricted to opinionated and editorial content, but also can be found in straight news reporting.

\section{Threat and Efficacy Information in the Context of Media Coverage of Climate Change}

Our conceptualization of threat and efficacy is informed by the Extended Parallel Process Model (EPPM), political science approaches to efficacy, and scholarship on media framing. According to the EPPM (Witte, 1992) effective risk communication requires information about threat as well as ways to reduce the threat (i.e., efficacy). Individuals appraise a threat on the basis of its perceived severity and their perceived susceptibility to the threat. Assuming that a threat is deemed significant and personally relevant, individuals who believe they have response efficacy (an action that can address the threat) and self-efficacy (the ability to carry out the action) will cognitively process information about the risk and adopt behaviors to avoid the risk. In contrast, if either self or response efficacy is low, individuals will attempt to manage their fear through maladaptive coping strategies. In the context of climate change, this may mean denying that climate change is a serious problem or relying on one's partisan predispositions for interpreting information about the problem.

The EPPM is often applied in health contexts, where risk reduction involves voluntary behavior change such as condom use. Although individual-level adoption of energy efficient behaviors may help reduce carbon emissions, widespread behavior change is constrained by modern society's high carbon infrastructure and institutions (Lorenzoni, Nicholson-Cole, \& 
Whitmarsh, 2007). Thus, the ability to mitigate climate change requires changes at the policy level and, as such, necessitates individual engagement in the political sphere (Ockwell, Whitmarsh, \& O’Neill, 2009). In a previous study (Authors, 2014), we proposed merging the EPPM with political science approaches to efficacy, specifically incorporating concepts of internal efficacy (similar to self-efficacy), which captures one's perceived ability to take political action, and external efficacy, which captures the belief that the government will respond to public demands (Craig, Niemi, \& Silver, 1990). People who are high in internal and external efficacy are more likely to try to influence political decisions through voting, campaigning, protesting, and other forms of participation (e.g., Finkel, 1985; Rosenstone \& Hansen, 2003). Response efficacy, as conceptualized in the EPPM, is also relevant to political engagement, in that it captures the perceived effectiveness of the political response to reduce the threat (Lubell, 2003). Thus, a message that fosters political engagement with climate change should provide information about self (internal), external, and response efficacy, as well as threat.

News stories can convey threat and efficacy information about climate change in three ways. First, a news story can do so directly by providing explicit details about the susceptibility and severity of a climate change threat and the likelihood of a personal or political action being successful in terms of self, external, and response efficacy. Although climate change lacks a simple or straightforward solution, there are nonetheless a variety of potential actions that individuals and policymakers can take to address the problem, and mediated information about the efficacy of these actions can help the public better understand what is at stake and how they can respond to the relevant risks. For example, a news story can describe whether individuals can easily take steps to address climate change, either in their personal or political behavior (selfefficacy); whether government officials are likely to respond to public opinion or calls for action 
(external efficacy); and whether the proposed actions are likely to be effective at slowing climate change (response efficacy).

Second, news stories can communicate threat and efficacy indirectly, by depicting the impacts and actions to which they respectively relate. For example, O’Neill \& Nicholson-Cole (2009) found that images of climate change impacts, such as devastating floods, increased the perceived importance of the issue but also made people feel powerless, whereas images depicting actions that address climate change, such as wind turbines, triggered feelings of efficacy but failed to evoke a sense of issue importance. This implies that representations of both impacts and actions are needed in order to encourage judgments of sufficient threat and efficacy.

Finally, the frames used to discuss climate change impacts and actions, respectively, can serve as vehicles for communicating threat and efficacy. Framing is the process by which a particular aspect of an issue is granted special emphasis, relative to other aspects of that issue (Entman, 1993). News about climate change can highlight any number of different issue dimensions, including environmental, economic, public health, national security, morality, political conflict, and public accountability, and these framing choices affect how people interpret information about climate change (for a review, see Authors, 2014; Nisbet, 2009). Prior research suggests that certain climate change frames may be particularly well-suited for conveying threat. For example, framing climate change in terms of its public health impacts may help localize the issue and make it more personally relevant (Maibach, Nisbet, Baldwin, Akerlof, \& Diao, 2010). Similarly, the way actions are framed can affect the communication of efficacy. For example, framing climate solutions in terms of political conflict may emphasize the selfinterested motivations of political leaders, thereby undermining efficacy (Cappella \& Jamieson, 1997). Thus, in order to fully understand how the media represent the threat of climate change 
and efficacy for actions to address it, it is important to evaluate how climate impacts and actions are differentially framed.

Our prior study of U.S. network TV news (Authors, 2014) found that although impacts and actions were each discussed in a majority of broadcasts, they were infrequently discussed in the same broadcast. Moreover, while news coverage regularly conveyed explicit information about the threat climate change poses to U.S. audiences, explicit discussion of efficacy information was relatively uncommon. Finally, climate change impacts were framed chiefly in terms of environmental consequences, whereas climate change actions were framed predominantly in terms of political conflict. This prior study, however, was restricted to network TV news and, given the homogeneity of broadcasts across networks, did not provide an opportunity to evaluate representations of threat and efficacy as sources of ideological differences in climate change coverage. Thus, the present study permits us not only to observe whether the aforementioned patterns generalize to newspaper coverage, but also to uniquely evaluate whether representations of threat and efficacy systematically vary between newspapers.

\section{How Journalistic Norms and Practices Influence Climate Change Reporting}

To guide their selection and presentation of news, journalists rely on professional norms and values, such as drama, personalization, and balance (Bennett, 2009), and these may have implications for how threat and efficacy are represented in climate change reporting. For example, privileging personalized stories and dramatic exemplars may skew climate coverage to focus disproportionately on sensational impacts, such as extreme weather events or collapsing ice shelves, or on the political conflict and strategy inherent in climate policy discourse. The U.S. policy process has become increasingly polarized, both in general (Layman, Carsey, \& Horowitz, 2006) and in the specific context of climate change (Guber, 2012), and this conflict is reflected in 
news framing of the issue (Boykoff, 2007b). Journalistic norms of balance often lead to a hesaid, she-said accounting of divisive issues that relies heavily on official sources (Bennett, Lawrence, \& Livingston, 2007). This especially may be true as news organizations reduce their science reporting staffs (Russell, 2010), thereby limiting the resources available to delve into the many facets of proposed climate solutions and their relative efficacy. Reliance on official sources also may lead journalists to focus on government actors at the expense of citizen-led action and the efficacy of those actions (Entman \& Rojecki, 1993).

Recent research, based on interviews with environmental journalists, highlights how journalistic norms and practices influence reporting about climate change. For example, Brüggemann and Engesser (2014) find evidence for an "interpretive community" of journalists united around the Intergovernmental Panel on Climate Change (IPCC) consensus on climate change, such that climate journalists accept the main propositions of this international scientific body and use these as an anchoring point for their coverage. Among reporters who cover climate change, there is a sense that the science is settled; as such, the views of climate skeptics are seen as having no place in stories about climate science (Brüggemann \& Engesser, 2014; Gibson, Craig, Harper, \& Alpert, 2015; Hiles \& Hinnant, 2014). However, when covering climate change policy - which invites debate and conflict - journalists still see a need for explicit balance that includes the views of climate skeptics (Hiles \& Hinnant, 2014). Climate reporters view their role primarily as informational or interpretive, and they eschew an advocacy role (Brüggemann \& Engesser, 2014; Gibson et al., 2015; Hiles \& Hinnant, 2014). At the same time, the incremental and abstract characteristics of climate change defy journalistic values of newsworthiness (Gibson et al., 2015). As a way to make climate change seem more relevant to their audiences and their editors, reporters try to connect climate change to local impacts (Gibson et al., 2015; Hiles \& 
Hinnant, 2014). Journalists also point to the economic pressures faced by news organizations as a constraint on quality climate change reporting. As science reporters are downsized and coverage of climate change moves from knowledgeable specialists to generalists who are spread thin and lack expertise in climate science or policy, there is a concern among journalists that this will produce superficial reporting and possibly encourage false balance (Gibson et al., 2015).

\section{Newspapers as a Source of Threat and Efficacy Information about Climate Change}

In 2012, although the Internet was the most popular source of science information among Americans, the majority of those who cited the Internet as their top source reported that they primarily consulted online editions of print newspapers (National Science Board, 2014). In total, approximately one third of Americans said that they get their science news from newspapers, either online or in print (National Science Board, 2014). Although the provision of efficacy information in newspaper coverage has been studied in the context of health risks like infectious diseases (e.g., Dudo, Dahlstrom, \& Brossard, 2007; Evensen \& Clarke, 2012), ours is the first study to do so in the context of a risk like climate change that also has strong political dimensions. Also, prior studies have focused solely on mentions of actions that can be taken to address a health risk and not, as we do, on the likely effectiveness of these actions; in this way, our approach more closely approximates self, external, and response efficacy as conceptualized in the risk communication and political science literature. Nonetheless, these prior analyses found that personal efficacy actions receive scant attention in newspapers. Somewhat more prevalent was information about societal efficacy, or actions that government and official actors can take to mitigate a risk (Evensen \& Clarke, 2012).

In political communication scholarship, "mobilizing information" refers to the tactical and logistical information in news stories that allows people to act on pre-existing attitudes 
(Lemert, 1981). This, too, has been found to be rare (Lemert, 1981), particularly in newspaper reporting about controversial political issues, ostensibly because journalists see such information as departing from objectivity (Lemert, 1984). Mobilizing information also has been conceptualized more broadly to account for "the potential of news discourse to shape the identity of a community and motivate it to act collectively" and has been found to vary appreciably across newspapers (Nicodemus, 2004, p. 174).

\section{Differences in Climate Change Coverage across News Outlets}

In today's high-choice media environment, audiences increasingly can select news sources that cohere with their interests, values, and opinions (Stroud, 2011). This selective exposure, in turn, creates an incentive for competing media organizations, driven by market considerations, to slant their coverage in the direction of their audience's existing beliefs (Mullainathan \& Shleifer, 2005). Consistent with this trend, audiences of leading newspapers differ in their ideological make-up. For example, readers of The New York Times are more liberal than those of USA Today or The Wall Street Journal (Gentzkow \& Shapiro, 2011). And prior research suggests that the political slant of newspapers is related to - and may be a response to the ideological composition of their readership (Gentzkow and Shapiro, 2010). It is widely understood that the editorial slant of The Wall Street Journal is conservative, while the editorial slant of The New York Times is liberal. However, Groseclose and Milyo (2005) also located the ideological slant of news coverage in The New York Times as far to the left of center and USA Today as closest to center, while Gentzkow and Shapiro (2010) found that The Wall Street Journal is more conservative in its news coverage than the Washington Post, New York Times, and USA Today. Moreover, although research has found that U.S. newspapers, in aggregate, do not exert a partisan political bias (D’Alessio \& Allen, 2000), other studies have shown that the 
tone of political news coverage in individual newspapers is colored by their editorial stance (e.g., Druckman \& Parkin, 2005).

The general ideological biases of individual news outlets may extend to the specific issue of climate change. In a study of the British elite press, Carvalho (2007) found that ideological perspectives were embedded in representations of scientific claims about climate change. In the U.S., a coordinated climate denial movement has relied on conservative media to disseminate claims that undermine concerns about and efforts to address climate change (Dunlap \& McCright, 2011). A content analysis of cable news outlets showed that the conservative-leaning Fox News was more likely to challenge claims about the reality and human causes of climate change than either MSNBC or CNN (Feldman, Maibach, Roser-Renouf, \& Leiserowitz, 2012). Nisbet (2011) found that major U.S. news organizations, including The New York Times and The Washington Post, overwhelmingly conveyed the "consensus" view that climate change is real and humans play a role. The one exception was The Wall Street Journal, which - predominantly in its editorial pages - often adopted a "falsely balanced" view that stressed climate change uncertainty, or a "dismissive" view that denied the reality of anthropogenic climate change.

This prior research locates source differences in climate coverage primarily in opinion content; however, non-editorial news stories also may convey ideological standpoints but do so less overtly, such as in their representations of threat and efficacy. Thus, following from our conceptual framework, we analyze source differences in straight news reporting across three categories of variables: (1) discussion of impacts and actions, (2) discussion of threat, self, external, and response efficacy, and (3) framing of impacts and actions. We hypothesize that The Wall Street Journal - given its relatively conservative editorial slant and readership - will be less likely to emphasize climate impacts $(H 1)$ and threat susceptibility $(H 2)$ and will be more likely to 
emphasize negative efficacy information (H3) than The New York Times, The Washington Post, and USA Today. Investigations involving actions, specific types of efficacy, and frames are considered exploratory; thus, we do not offer explicit hypotheses for these variables.

\section{Method}

\section{Sampling}

We conducted a content analysis of news stories about climate change in The New York Times (NYT), The Wall Street Journal (WSJ), Washington Post (WP), and USA Today (USA) between January 1, 2006 and December 31, 2011. This time period provides a recent, multi-year view of how leading U.S. newspapers covered climate change and includes several newsworthy events, such as the release of the third Intergovernmental Panel on Climate Change (IPCC) report in 2007, the award of the 2007 Nobel Peace Prize to the IPCC and Al Gore, and the 2009 UN Climate Change Conference in Copenhagen. This period also includes failed attempts to pass cap-and-trade legislation in the U.S. in 2009 and 2010, as well as organized protests, in 2011, against the Keystone XL pipeline. In order to locate this time period within the broader issue attention cycle, Figure 1 plots the total number of news articles that appeared each month in NYT, WSJ, WP, and USA between January 1, 2000 and September 30, 2014. The time interval for this study, represented between the two vertical lines in Figure 1, was a period of relatively heightened media attention to climate change. ${ }^{1}$

--Figure 1 about here--

To cull the study sample, we used Factiva to identify news stories from the four newspapers that included the terms "climate change" or "global warming" in the headline or lead, excluding editorials, opinion columns, and book and entertainment reviews. The search yielded 3,274 articles after excluding 94 duplicates. We sampled every $5^{\text {th }}$ article in 
chronological order, regardless of source, yielding a systematic random sample of 654 articles. A graduate student scanned the articles and deleted 75 stories that did not qualify as substantive news about climate change. These stories were replaced by finding each deleted article in the original search results and sampling the next sequential article. During coding, an additional 12 articles were disqualified from the sample. These were not replaced, and the final sample included 642 articles.

\section{Coding Procedure}

The coding procedure used a binary present/not present format to assess the discussion of climate change impacts and actions, inclusion of explicit threat and efficacy information, and the framing of impacts and actions. Three coders performed the coding. Coders were trained on the codebook and underwent several rounds of practice coding with sub-samples of approximately 60 articles. Where discrepancies arose, the coders discussed the examples to resolve disagreement, and the codebook was refined as needed (e.g., by increasing the specificity of variable definitions or providing examples of when certain codes should or should not be applied). The full codebook is available by request. To assess intercoder reliability, all coders coded a random subset of articles comprising $20 \%$ of the sample. Krippendorf's alpha for all variables ranged from $.7-1.0$. The variables are described below.

Impacts and actions. Each article was coded for whether it discussed at least one impact of climate change and whether it discussed at least one mitigative or adaptive action that can be taken to address climate change. In order to provide a more nuanced understanding of the actions discussed, we also coded for action type, differentiating between individual behavior change such as installing energy-efficient lights, individual or group political action or advocacy such as 
participating in a protest, business and technological innovation such as developing fuel-efficient vehicles, and governmental action such as regulating greenhouse gas emissions.

Threat. Articles that mentioned climate impacts were coded for explicit information about the threat posed by those impacts. Typical news coverage of climate change generally does not offer a comparative level of threat severity that different impacts may pose. News coverage, however, often includes information about the location and timing of climate impacts, both of which bear on individuals' perceived susceptibility. Thus, we assessed threat by focusing on the temporal and geographic proximity of climate change impacts, assuming a national audience. Specifically, we coded for whether climate impacts were discussed as occurring in the present day, past, or future, and whether the location of impacts was indicated as the United States, polar regions, developing countries, or non-U.S. developed countries.

Efficacy. If an article mentioned climate change actions, we coded for whether it included explicit positive and negative information, respectively, related to self-efficacy, external efficacy, and response efficacy. Table 1 lists definitions and examples of each efficacy type. --Table 1 about here--

Framing. We coded impacts and actions separately for the following frames: environment, public health, national security, economic, secular morality, religious morality, public accountability, and conflict/strategy. Articles that mentioned climate impacts were coded for whether climate change was discussed as having effects on 1) the environment (e.g., melting glaciers, threats to plants and animals, etc.), 2) public health (e.g., asthma, allergies, infectious disease, etc.), 3) national security (e.g., displacement of populations, violent conflict, etc.), and 4) the economy (e.g., financial costs to government or industry); no instances were found in which impacts were discussed in terms of morality, public accountability, or conflict/strategy. 
Articles that mentioned actions to address climate change were coded for whether those actions were discussed in terms of influencing 1) the environment, 2) public health, 3) national security, 4) the economy in a positive way (e.g., new green jobs), or 5) the economy in a negative way (e.g., economic stagnation due to greenhouse gas regulation). We also coded for whether action to address climate change was discussed in terms of 6) a secular moral responsibility (stewardship or an obligation to protect the earth), 7) a religious moral responsibility (invokes god or religion as a reason for action), 8) a need for greater public accountability (discussed as a matter of research or policy in the public interest or serving special interests; e.g., stories about government officials suppressing scientific information, the falsification of climate data, or the politicization of climate change), or 9) a conflict or power struggle between politicians or stakeholder groups (e.g., Democrats and Republicans battling over legislation, international disputes over climate policy, climate change as an election issue, etc.).

\section{Results}

Of the 642 sampled articles, 226 (35.2\%) were from NYT, 134 (20.9\%) from WSJ, 215 $(33.5 \%)$ from WP, and 67 (10.4\%) from USA. ${ }^{2}$ Thus, NYT and WP devoted the greatest coverage to climate change, and USA the least (see also Figure 1). ${ }^{3}$ Below, we first report on the discussion of climate change impacts and actions across newspapers. We next report on coverage of explicit threat and efficacy information. Finally, we present the results for how impacts and actions were framed. Newspaper source effects on each variable were assessed using a chisquare test, and when a significant overall relationship was found, pairwise comparisons of column proportions were conducted using the Bonferroni correction.

\section{Impacts and Actions}


Impacts. Looking to Table 2, overall, $41.1 \%$ of articles mentioned at least one climate impact. Consistent with $H 1$, WSJ was significantly less likely to discuss impacts than the other three papers, doing so in only $21.6 \%$ of stories - approximately half as frequently as in NYT, WP, and USA (see tables for chi-square statistics and pairwise newspaper comparisons).

--Table 2 about here--

Actions. Eighty-five percent of articles discussed at least one action that could be taken to address climate change (see Table 2). Of the four newspapers, WSJ was especially likely to discuss actions, doing so in $93.3 \%$ of its coverage, which was significantly higher than NYT $(83.6 \%)$ and WP (82.3\%). Government action, which was referenced in approximately twothirds of articles, was the most frequent action type discussed, followed by technological and business innovation. WSJ was significantly more likely than the other three papers to discuss government action. WP was the least likely to discuss technological innovation and did so with significantly less frequency than NYT and WSJ.

The co-occurrence of impacts and actions. Despite the large proportion of stories that discussed actions, impacts were more likely to be discussed without actions than with. Specifically, $36.4 \%$ of stories that discussed actions also discussed impacts, whereas $67.7 \%$ of stories that did not mention actions discussed impacts $\left(X^{2}(1, N=642)=32.95, p<.001\right)$. Overall, just $31 \%$ of stories discussed both impacts and actions. This pattern did not differ systematically between newspapers.

\section{Threat and Efficacy}

Threat susceptibility. Looking to Table 3, overall, $30.1 \%$ of stories discussed presentday impacts. In support of $H 2$, WSJ was significantly less likely to discuss present-day impacts than the other three papers, doing so in only $12.7 \%$ of articles; the other papers mentioned 
present-day impacts at least twice as frequently. The U.S. was the most frequently discussed location of impacts, referenced in $14.6 \%$ of articles overall. Also consistent with $H 2$, WSJ was least likely to discuss U.S. impacts, doing so in $6 \%$ of its coverage and significantly less than WP and USA. ${ }^{4}$ Overall, $11.5 \%$ of stories discussed both present-day and U.S. impacts.

--Table 3 about here--

Efficacy. Of the positive efficacy types, response efficacy was discussed most frequently, appearing in $16.7 \%$ of coverage (see Table 3). Positive external and self-efficacy were rarely, if ever, discussed. These patterns did not vary significantly between newspapers.

Of the negative efficacy types, response efficacy again was discussed most frequently, appearing in $21.5 \%$ of articles. Consistent with $H 3$, WSJ discussed negative response efficacy most often $(32.1 \%)$, and this was significantly greater than WP $(15.8 \%) .{ }^{5}$ Mentions of negative external and self-efficacy were relatively rare, with no differences across papers.

We also computed summary variables to capture whether articles included any type of positive efficacy information (i.e., self or external or response) and whether they included any type of negative efficacy information (i.e., self or external or response). One fifth of articles (20.2\%) discussed positive efficacy, with no differences between papers. Similarly, $24.3 \%$ of articles discussed negative efficacy. However, as $H 3$ predicted, there were significant differences between papers, such that WSJ was most likely to discuss negative efficacy and WP least likely.

\section{Framing}

Impacts. As shown in Table 4, an environmental impact frame was used most often, appearing in $36.4 \%$ of stories. The next most frequently used impact frame was public health (12.6\%), followed by economic $(7.5 \%)$ and national security $(4.4 \%)$. WSJ was significantly less 
likely than the other three papers to use an environmental impact frame and was significantly less likely than USA to use public health and economic frames. ${ }^{6}$

--Table 4 about here--

Actions. Among action frames, a conflict frame was used most often, appearing in $42.2 \%$ of articles. WSJ was most likely to use conflict framing, doing so in 53\% of its coverage, which was significantly greater than NYT. A negative economic frame was used next most frequently overall (20\%), and was used significantly more often by WSJ than NYT and WP. Positive economic (15.9\%) and environmental (10\%) frames were used third and fourth most frequently, respectively. The remaining action frames (public health, national security, public accountability, morality-secular, and morality-religious) appeared sporadically, with none used in more than $8 \%$ of stories. Of these, only the secular morality frame manifested significant differences between newspapers: It was used significantly less frequently in WSJ than in USA. ${ }^{7}$

\section{Discussion}

This study analyzed how The New York Times, The Wall Street Journal, The Washington Post, and USA Today represent the threat of climate change and efficacy for actions to address it and, in particular, whether systematic differences exist between newspapers in these representations. In aggregate, the results suggest that leading U.S. newspapers discuss climate change in ways that have the potential to leave readers feeling unconcerned about climate change, disempowered, or both. First, across all newspapers, impacts and actions were more likely to be discussed separately than together in the same article. Thus, audiences are provided with information about the impacts of climate change without information about how to reduce those impacts or - more often - are informed of actions to address climate change without the context to appreciate why those actions are needed. Less than half of coverage discussed the 
impacts of climate change, and an even smaller percentage represented climate change as a threat that is immediate to the American public, despite evidence that climate change poses a current and increasing threat to the U.S. (Melillo et al., 2014; Romero-Lankao et al., 2014). In the absence of a strong perceived threat, individuals may fail to even process or respond to risk information (Witte, 1992).

Although, overall, the newspapers strongly emphasized actions to address climate change, discussions of individual behavior change and political action and, correspondingly, of self-efficacy and external efficacy were mostly absent. These findings are consistent with other research that has compared coverage of individual versus governmental actors (e.g., Entman \& Rojecki, 1993; Evensen \& Clarke, 2012), and suggest that there is little readers can glean from these stories about what actions they, as individuals, can take personally or politically to address climate change. Even information about response efficacy - the most discussed type of efficacy - appeared in no more than a third of coverage. Moreover, rather than focusing on specific positive or negative consequences of taking action, the dominant action frame stressed political conflict and strategy, which research connects with high levels of cynicism toward government (Cappella \& Jamieson, 1997) and likely portrays climate change as a seemingly intractable problem whose potential solutions are mired in the competition and self-interested motivations of dueling political elites. Absent a sense of efficacy, threat information is likely to encourage problem denial and other forms of defensive processing (Byrne \& Hart, 2009).

These coverage patterns may stem from a dearth of resources to report on science and environmental issues, a lack of specialized knowledge among reporters (Patterson, 2013), and/or inherent structural biases in the news that privilege drama and conflict (Bennett, 2009). The tendency to omit efficacy information and decouple information about impacts and actions may 
arise from the perception among journalists that doing otherwise constitutes advocacy, as has been suggested in prior studies of "mobilizing information" in political reporting (Lemert, 1984). In comparing coverage between newspapers, we found significant differences for more than half of the variables studied, driven primarily by The Wall Street Journal. In support of H1 and H2, The Wall Street Journal was least likely of the four papers to discuss the impacts of and threat posed by climate change. Although The Wall Street Journal offered the most coverage of actions, this was primarily in the context of negative efficacy and conflict framing, both of which appeared more frequently in The Wall Street Journal than in the other papers, consistent with H3. On the other hand, the inclusion of positive efficacy information was similar across newspapers. The Wall Street Journal also was least likely to frame climate change in terms of negative economic impacts and most likely to highlight the negative economic consequences of taking action. This is notable, given that the paper emphasizes business and financial news, and its discussion of economic issues is thus likely to be especially salient to its readers. Finally, a morality action frame, which prior research has found is particularly likely to promote engagement (Markowitz \& Shariff, 2012), was used significantly less in The Wall Street Journal than in the other papers. To our knowledge, this is the first study to locate systematic differences in climate change news coverage across U.S. newspapers, differences that are relatively subtle but which may nonetheless have important effects on audience engagement. Moreover, given the relatively conservative readership of The Wall Street Journal, these differences could exacerbate ideological polarization on climate change (Feldman et al., 2014).

Overall, these findings raise normative questions about both what is a sufficient amount of threat and efficacy information in news reporting about climate change and how realistic it is to expect this sort of coverage. Certainly journalists should not invent efficacy angles when none 
exist; however, it is notable that self and external efficacy messages - both positive and negative - were limited during a time period that included extensive debate over cap-and-trade legislation in U.S. Congress, high-profile and arguably successful public protests against the Keystone pipeline, and an international climate summit that invited widespread citizen demonstrations. Further, in highlighting newspapers' disproportionate use of conflict framing, we are not advocating for the removal of political debate from climate reporting, only pointing out that discussions of climate change actions tend to focus on partisan disagreement, strategy, and the "players" involved, rather than on the relative benefits and costs of various courses of action. Although a stronger focus on efficacy in climate reporting is unlikely to singlehandedly overcome the barriers to climate action in the U.S., an analysis of "solutions-based journalism" (see www.solutionsjournalism.org) has found that when news stories discuss responses to entrenched sociopolitical problems, this increases readers' perceived efficacy, optimism, and interest, among other outcomes, relative to stories that focus solely on problems (Curry \& Hammonds, 2014).

As with all research, it is important to note the present study's limitations. First, this study focuses on U.S. newspapers and cannot comment on the representation of threat and efficacy in newspapers from other nations; comparative studies using the current framework offer an important direction for future research. We also only sampled from national newspapers, which restricts our ability to assess threat susceptibility more precisely. This also excludes local newspapers, which may cover climate change differently. We also did not link claims about threat and efficacy to specific sources within news stories. This may be a valuable direction for future research, given ideological differences in public trust of scientists, politicians, and other institutional actors (e.g., Hmielowski, Feldman, Myers, \& Leiserowitz, 2014). Finally, the nature 
of content analysis necessarily constrains our ability to draw inferences about news effects. Although evidence from prior research is suggestive (Curry \& Hammonds, 2014; Feinberg \& Willer, 2012; Witte, 1992), the next step is to test effects on public opinion and polarization using experimental and survey methods. Another useful direction for future research is to identify the particular aspects of journalistic practice and newsroom culture that give rise to the patterns reported herein.

The current study offers a unique marriage of the EPPM and political science concepts of internal and external political efficacy, which can be applied to studies of media content and effects not only in the context of climate change but also in the context of other risk issues that have a strong political dimension. Together with our previous findings (Authors, 2014), the current results continue to suggest that the U.S. mainstream news media cover climate change in ways that may be suboptimal for public engagement. Further, in an advance over prior research, the results point to sources of ideological differences in news coverage of climate change that may have otherwise gone unnoticed if not analyzed through the framework of threat and efficacy. On a practical level, considering that these differences appeared in non-editorial news coverage, this study offers insights for journalists who may not be aware of how their reporting choices affect the representation of climate change within the public sphere. 


\section{References}

Alliance for Audited Media. (2013). Top 25 U.S. newspaper for March 2013. Retrieved from http://www.auditedmedia.com/news/blog/top-25-us-newspapers-for-march-2013.aspx

Bennett, W. L. (2009). News: The politics of illusion (8th ed.). New York: Longman.

Bennett, W. L., Lawrence, R. G., \& Livingston, S. (2007). When the press fails. Chicago: University of Chicago Press.

Boykoff, M. T. (2007a). Flogging a dead norm? Newspaper coverage of anthropogenic climate change in the United States and United Kingdom from 2003 to 2006. Area, 39(4), 470481. doi: 10.1111/j.1475-4762.2007.00769.x

Boykoff, M. T. (2007b). From convergence to contention: United States mass media representations of anthropogenic climate change science. Transactions of the Institute of British Geographers, 32(4), 477-489. doi: 10.1111/j.1475-5661.2007.00270.x

Boykoff, M. T., \& Boykoff, J. M. (2004). Balance as bias: Global warming and the US prestige press. Global Environmental Change, 14, 125-136. doi:10.1016/j.gloenvcha.2003.10.001

Brüggemann, M., \& Engesser, S. (2014). Between consensus and denial climate journalists as interpretive community. Science Communication, 36(4), 399-427. doi: 1075547014533662.

Byrne, S., \& Hart, P. S. (2009). The boomerang effect: A synthesis of findings and a preliminary theoretical framework. Communication yearbook (Vol. 33).

Cappella, J. N., \& Jamieson, K. H. (1997). Spiral of cynicism: The press and the public good. New York: Oxford University Press.

Carvalho, A. (2007). Ideological cultures and media discourses on scientific knowledge: Re- 
reading news on climate change. Public Understanding of Science, 16(2), 223-243. doi: $10.1177 / 0963662506066775$

Craig, S. C., Niemi, R. G., \& Silver, G. E. (1990). Political efficacy and trust: A report on the NES pilot study items. Political Behavior, 12(3), 289-314. doi:10.1007/BF00992337

Curry, A. L., \& Hammonds, K. H. (2014). The power of solutions journalism. A joint report of the Engaging News Report and Solutions Journalism Network. Retrieved from http://solutionsjournalism.org/wp-content/uploads/2014/06/ENP_SJN-report.pdf

D’Alessio, D., \& Allen, M. (2000). Media bias in presidential elections: A meta-analysis. Journal of Communication, 50(4), 133-156. doi: 10.1111/j.1460-2466.2000.tb02866.x

Druckman, J. N., \& Parkin, M. (2005). The impact of media bias: How editorial slant affects voters. Journal of Politics, 67(4), 1030-1049. doi: 10.1111/j.1468-2508.2005.00349.x

Dudo, A. D., Dahlstrom, M. F., \& Brossard, D. (2007). Reporting a potential pandemic: A riskrelated assessment of avian influenza coverage in U.S. newspapers. Science Communication, 28, 429-454. doi: 10.1177/1075547007302211

Dunlap, R. E., \& McCright, A. M. (2011). Organized Climate Change Denial. The Oxford Handbook of Climate Change and Society (pp. 144-160). Oxford, UK: Oxford University.

Entman, R. M. (1993). Framing: Toward clarification of a fractured paradigm. Journal of Communication, 43(4), 51-58.

Entman, R. M., \& Rojecki, A. (1993). Freezing out the public: Elite and media framing of the U.S. anti-nuclear movement. Political Communication, 10(2), 155-173. doi: $10.1080 / 10584609.1993 .9962973$

Evensen, D. T., \& Clarke, C. (2012). Efficacy information in media coverage of infectious 
disease risks: An ill predicament? Science Communication, 34, 392-418. doi:

$10.1177 / 1075547011421020$

Feinberg, M., \& Willer, R. (2011). Apocalypse soon? Dire messages reduce belief in global warming by contradicting just-world beliefs. Psychological Science, 22(1), 34-38. doi: $10.1177 / 0956797610391911$

Feldman, L., Maibach, E., W., Roser-Renouf, C., \& Leiserowitz, A. (2012). Climate on cable: The nature and impact of global warming coverage on Fox News, CNN, and MSNBC. International Journal of Press/Politics, 17(1), 3-31. doi: 10.1177/1940161211425410

Feldman, L., Myers, T. A., Hmielowski, J. D., \& Leiserowitz, A. (2014). The mutual reinforcement of media selectivity and effects: Testing the reinforcing spirals framework in the context of global warming. Journal of Communication, 65(4), 590-611. doi: $10.1111 /$ jcom. 12108

Finkel, S. E. (1985). Reciprocal effects of participation and political efficacy: A panel analysis. American Journal of Political Science, 29(4), 891-913. doi:10.2307/2111186

Gentzkow, M. \& Shapiro, J.M. (2010). What drives media slant? Evidence from US daily newspapers. Econometrica, 78(1), 35-71. doi: 10.3982/ECTA7195

Gentzkow, M. \& Shapiro, J.M. (2011). Ideological segregation online and offline. The Quarterly Journal of Economics, 126(4), 1799-1839. doi: 10.1093/qje/qjr044

Gibson, T. A., Craig, R. T., Harper, A. C., \& Alpert, J. M. (2015). Covering global warming in dubious times: Environmental reporters in the new media ecosystem. Journalism. doi: 1464884914564845 .

Groseclose, T., \& Milyo, J. (2005). A measure of media bias. The Quarterly Journal of Economics, 120(4), 1191-1237. doi: 10.1162/003355305775097542 
Guber, D. (2012). A cooling climate for change? Party polarization and the politics of global warming. American Behavioral Scientist, 57(1), 93-115. doi:

$10.1177 / 0002764212463361$

Hiles, S. S., \& Hinnant, A. (2014). Climate change in the newsroom: Journalists' evolving standards of objectivity when covering global warming. Science Communication, 36(4), 428-453. doi: 1075547014534077.

Hmielowski, J. D., Feldman, L., Myers, T. A., \& Leiserowitz, A. (2014). An attack on science? Media use, trust in scientists, and perceptions of global warming. Public Understanding of Science, 23(7), 866-883. doi: 10.1177/0963662513480091

IPCC. (2013). Summary for policymakers. In T. F. Stocker, D. Qin, G. K. Plattner, M. Tignor, S.K. Allen, J. Boschung, et al. (Eds.), Climate Change 2013: The Physical Science Basis. Contribution of Working Group I to the Fifth Assessment Report of the IPCC. Retrieved from http://www.climatechange2013.org/images/report/WG1AR5_SPM_FINAL.pdf

Layman, G. C., Carsey, T. M., \& Horowitz, J. M. (2006). Party polarization in American politics: Characteristics, causes, and consequences. Annual Review of Political Science, 9, 83-110. doi: 10.1146/annurev.polisci.9.070204.105138

Lemert, J. B. (1977). Journalists and mobilizing information. Journalism Quarterly, 54(4), 721726.

Lemert, J. B. (1984). News context and the elimination of mobilizing information: An experiment. Journalism Quarterly, 61(2), 243-259.

Levendusky, M. (2013). How partisan media polarize America. Chicago: University of Chicago Press.

Lorenzoni, I., Nicholson-Cole, S., \& Whitmarsh, L. (2007). Barriers perceived to engaging with 
climate change among the UK public and their policy implications. Global Environmental Change, 17(3-4), 445-459. doi: 10.1016/j.gloenvcha.2007.01.004

Lubell, M. (2003). Collaborative institutions, belief-systems, and perceived policy effectiveness. Political Research Quarterly, 56(3), 309-323. doi:10.1177/106591290305600306

Maibach, E. W., Nisbet, M. C., Baldwin, P., Akerlof, K., \& Diao, G. (2010). Reframing climate change as a public health issue: an exploratory study of public reactions. BMC Public Health, 10(1), 299-309. doi:10.1186/1471-2458-10-299

Markowitz, E. M., \& Shariff, A. F. (2012). Climate change and moral judgment. Nature Climate Change, 2(4), 243-247. doi:10.1038/nclimate1378

McCright, A. M., \& Dunlap, R. E. (2011). The politicization of climate change and polarization in the American public's views of global warming, 2001-2010. Sociological Quarterly, 52(2), 155-194. doi:10.1111/j.1533-8525.2011.01198.x

Melillo, J. M., Richmond, T. C., \& Yohe, G. W., Eds. (2014). Climate change impacts in the United States: The third national climate assessment. U.S. Global Change Research Program. Retrieved from http://nca2014.globalchange.gov/downloads

Mullainathan, S., \& Shleifer, A. (2005). The market for news. American Economic Review, 95, 1031-1053. Retrieved from http://www.jstor.org/stable/4132704

National Science Board. 2014. Science and Engineering Indicators 2014. Arlington VA: National Science Foundation (NSB 14-01). Retrieved from http://www.nsf.gov/statistics/seind14/

Nicodemus, D. M. (2004). Mobilizing information: Local news and the formation of a viable political community. Political communication, 21, 161-176. doi:

$10.1080 / 10584600490443868$ 
Nisbet, M. C. (2009). Communicating climate change: Why frames matter for public engagement. Environment: Science \& Policy for Sustainable Development, 51(2), 12-23.

Nisbet, M. C. (2011). Climate shift: Clear vision for the next decade of public debate. Retrieved from http://climateshiftproject.org/wpcontent/uploads/2011/08/ClimateShift_report_June2011.pdf

O’Neill, S., \& Nicholson-Cole, S. (2009). “Fear won’t do it” Promoting positive engagement with climate change through visual and iconic representations. Science Communication, 30(3), 355-379. doi:10.1177/1075547008329201

Ockwell, D., Whitmarsh, L., \& O’Neill, S. (2009). Reorienting climate change communication for effective mitigation. Science Communication, 30(3), 305 -327. doi:10.1177/1075547008328969

Patterson, T. (2013). Informing the news. New York: Vintage.

Romero-Lankao, P., Smith, J. B., Davidson, D. J., Diffenbaugh, N. S., Kinney, P.L., Kirshen, P., et al. (2014). North America. In V. R. Barros, C.B. Field, D. J. Dokken, M.D. Mastrandrea, K. J. Mach, T. E. Billir, et al. (Eds.), Climate Change 2014: Impacts, Adaptation, \& Vulnerability. Part B: Regional Aspects. Contribution of Working Group II to the Fifth Assessment Report of the Intergovernmental Panel on Climate Change. Cambridge, UK: Cambridge University Press. Retrieved from http://www.ipcc.ch/pdf/assessment-report/ar5/wg2/WGIIAR5-Chap26_FINAL.pdf

Rosenstone, S. J., \& Hansen, J. M. (2003). Mobilization, participation, and democracy in America (1st ed.). New York: Pearson.

Russell, C. (2010). Covering controversial science: Improving reporting on science and public 
policy. In D. Kennedy \& G. Overholser (Eds.), Science and the Media (pp. 13-43). Cambridge, MA: American Academy of Arts and Sciences.

Stroud, N. J. (2011). Niche News. New York: Oxford University Press.

Witte, K. (1992). Putting the fear back into fear appeals: The extended parallel process model. Communication Monographs, 59(4), 329-349. doi:10.1080/03637759209376276 


\section{Footnotes}

${ }^{1}$ Article counts in Figure 1 were based on a search in Factiva for news articles that mentioned "global warming" or "climate change" in the headline or lead. The search excluded editorials, opinion articles, book reviews, sports, obituaries, weather, and calendar events.

${ }^{2}$ Although the sample was not stratified by newspaper, the sampling procedure yielded sample proportions for each newspaper that were highly similar to their population proportions: NYT: sample - 35.2\%, population - 39\%; WSJ: sample - 20.9\%, population - 19.3\%; WP: sample - $33.5 \%$, population - $32.1 \%$; USA: sample $-10.4 \%$; population $-9.3 \%$.

${ }^{3}$ Although not a focus of this study, we also examined over-time changes in coverage patterns. Across all variables, only two significant over-time differences emerged. Discussion of positive response efficacy was significantly higher in 2008 than in 2009 and 2011, and the environmental action frame was used significantly less frequently in 2007 than in any other year.

${ }^{4}$ Given that WSJ was significantly less likely to discuss impacts in the first place, it is also informative to examine differences between newspapers when only including those stories that discussed impacts $(N=264)$. When analyzing this subset, WSJ was still least likely to discuss present-day impacts and impacts occurring in the U.S. but did not differ significantly from any of the other papers. Thus, the significant differences on these variables in the full sample may have been driven by WSJ's less frequent discussion of impacts, in general. Still, it is important to see the small percentage of WSJ stories overall that discuss high threat impacts; thus, we focus our main discussion on those differences rather than on the differences only among stories that discussed impacts.

5 The pattern of significant differences across newspapers was identical when confining the analysis only to those stories that discussed actions. 
${ }^{6}$ When confining the analysis only to those stories that discussed impacts, WSJ was still least likely to use all four types of impact frames, but there were no statistically significant differences between newspapers for any of these frames.

${ }^{7}$ When confining the analysis only to those stories that discussed actions, differences between newspapers in the use of negative economic framing and secular morality framing remained significant; however, the difference between WSJ and NYT in the use of conflict framing became non-significant. 
Table 1

Operational Definitions and Examples for Efficacy Variables

\begin{tabular}{|c|c|c|}
\hline Concept & Operational Definition & Example \\
\hline Self Efficacy - Positive & $\begin{array}{l}\text { Indicates that individual action } \\
\text { to address climate change is } \\
\text { possible, easy, simple, etc. }\end{array}$ & $\begin{array}{l}\text { "But even without government } \\
\text { and industry making broad } \\
\text { changes, Toor is showing that } \\
\text { individuals and families can } \\
\text { make a significant difference on } \\
\text { their own." - USA 6/1/06 }\end{array}$ \\
\hline Self Efficacy - Negative & $\begin{array}{l}\text { Indicates that individual action } \\
\text { to address climate change is } \\
\text { impossible, difficult, hard, } \\
\text { expensive, etc. }\end{array}$ & $\begin{array}{l}\text { "the restaurant's owner... } \\
\text { acknowledged it was difficult to } \\
\text { decide to spend } 10 \text { to } 20 \text { percent } \\
\text { more for the containers, made } \\
\text { from potato starch, while opening } \\
\text { a business during the economic } \\
\text { downturn." - NYT } 2 / 23 / 10\end{array}$ \\
\hline External Efficacy - Positive & $\begin{array}{l}\text { Refers to the responsiveness } \\
\text { of political or corporate elites } \\
\text { to public opinion and/or calls } \\
\text { for action }\end{array}$ & $\begin{array}{l}\text { Richmond's planning } \\
\text { commission, which is vetting the } \\
\text { project, is siding with activists } \\
\text { who complained about the } \\
\text { environmental impact of the } \\
\text { dirtier fuel. - WSJ } 6 / 12 / 08\end{array}$ \\
\hline External Efficacy - Negative & $\begin{array}{l}\text { Refers to the failure of } \\
\text { political or corporate elites to } \\
\text { respond to public opinion } \\
\text { and/or calls for action }\end{array}$ & $\begin{array}{l}\text { "Americans' growing awareness } \\
\text { of global warming has yet to } \\
\text { translate into national policy } \\
\text { changes"- WP } 3 / 21 / 08\end{array}$ \\
\hline Response Efficacy - Positive & $\begin{array}{l}\text { Refers to the potential or } \\
\text { actual success of a specific } \\
\text { action or policy to address } \\
\text { climate change }\end{array}$ & $\begin{array}{l}\text { "He says that even a relatively } \\
\text { small-scale effort using such } \\
\text { methods 'could make a } \\
\text { significant dent in emissions on a } \\
\text { global level'." - USA } 2 / 11 / 10\end{array}$ \\
\hline Response Efficacy - Negative & $\begin{array}{l}\text { Refers to the lack of potential } \\
\text { or actual success of a specific } \\
\text { action or policy to address } \\
\text { climate change }\end{array}$ & $\begin{array}{l}\text { In recent months, however, U.N. } \\
\text { regulators who administer the } \\
\text { program have objected to dozens } \\
\text { of these developing-world } \\
\text { projects, ranging from } \\
\text { hydroelectric plants to wind } \\
\text { farms, questioning whether the } \\
\text { projects would produce a real } \\
\text { environmental payoff. - WSJ } \\
4 / 12 / 08\end{array}$ \\
\hline
\end{tabular}


Table 2

Discussion of Climate Impacts and Actions across Leading U.S. Newspapers

\begin{tabular}{l|cccccl}
\hline & Total & NYT & WSJ & WP & USA & Chi-sq. \\
\hline & $\%$ & $\%$ & $\%$ & $\%$ & $\%$ & \\
Impacts & 41.1 & $40.3_{\mathrm{a}}$ & $21.6_{\mathrm{b}}$ & $48.8_{\mathrm{a}}$ & $58.2_{\mathrm{a}}$ & $34.44^{* * *}$ \\
$\begin{array}{l}\text { Actions } \\
\text { Type }\end{array}$ & 85.0 & $83.6_{\mathrm{a}}$ & $93 . \mathrm{b}_{\mathrm{b}}$ & $82.3_{\mathrm{a}}$ & $82.1_{\mathrm{a}, \mathrm{b}}$ & $9.22^{*}$ \\
$\quad$ & & & & & & \\
$\quad$ Behavior Change & 9.7 & 6.6 & 7.5 & 13.0 & 13.4 & 6.99 \\
$\quad$ Political Advocacy & 13.6 & 13.3 & 13.4 & 14.0 & 13.4 & 0.05 \\
$\quad$ Government & 67.3 & $66.4_{\mathrm{a}}$ & $81.3_{\mathrm{b}}$ & $60.9_{\mathrm{a}}$ & $62.7_{\mathrm{a}}$ & $16.71^{* *}$ \\
$\quad$ Technology & 28.8 & $35.4_{\mathrm{a}}$ & $35.1_{\mathrm{a}}$ & $17 . \mathrm{7}_{\mathrm{b}}$ & $29.9_{\mathrm{a}, \mathrm{b}}$ & $20.38^{* * *}$ \\
$N$ & 642 & 226 & 134 & 215 & 67 & \\
\hline
\end{tabular}

Note. Chi-square tests were conducted with $d f=3$. Cell entries with different subscripts are significantly different from one another at $p<.05$ based on pairwise comparisons of column proportions using the Bonferroni correction. ${ }^{*} p<.05 . * * p<.01 . * * * p<.001$. 
Table 3

Coverage of Explicit Climate Threat and Efficacy Information across

Leading U.S. Newspapers

\begin{tabular}{l|cccccc}
\hline & Total & NYT & WSJ & WP & USA & Chi-sq. \\
\hline Threat & $\%$ & $\%$ & $\%$ & $\%$ & $\%$ & \\
Timing & & & & & & \\
Present & 30.1 & $28.3_{\mathrm{a}}$ & $12.7_{\mathrm{b}}$ & $39.5_{\mathrm{a}}$ & $40.3_{\mathrm{a}}$ & $32.08^{* * *}$ \\
Past & 11.4 & $8.0_{\mathrm{a}}$ & $4.5_{\mathrm{a}}$ & $16.7_{\mathrm{b}}$ & $19.4_{\mathrm{b}}$ & $19.37^{* * *}$ \\
Future & 22.0 & $20.4_{\mathrm{a}}$ & $13.4_{\mathrm{a}}$ & $22.8_{\mathrm{a}}$ & $41.8 \mathrm{~b}$ & $21.48^{* * *}$ \\
Location & & & & & & \\
U.S. & 14.6 & $13.7 \mathrm{a}, \mathrm{b}, \mathrm{c}$ & $6.0_{\mathrm{b}}$ & $18.6_{\mathrm{a}, \mathrm{c}}$ & $22.4_{\mathrm{c}}$ & $14.14^{* *}$ \\
Polar & 10.0 & $8.4_{\mathrm{a}, \mathrm{b}}$ & $4.5_{\mathrm{a}}$ & $14.9_{\mathrm{b}}$ & $10.4_{\mathrm{a}, \mathrm{b}}$ & $10.92^{*}$ \\
Developed & 7.9 & $7.1_{\mathrm{a}, \mathrm{b}}$ & $3.7_{\mathrm{a}}$ & $12.1_{\mathrm{b}}$ & $6.0_{\mathrm{a}, \mathrm{b}}$ & $8.90^{*}$ \\
Developing & 7.6 & 8.4 & 5.2 & 8.8 & 6.0 & 0.75 \\
Efficacy & 36.1 & 33.6 & 44.0 & 34.0 & 35.8 & 4.68 \\
Positive & 20.2 & 16.8 & 20.1 & 23.3 & 22.4 & 3.04 \\
Self & 3.3 & 1.8 & 1.5 & 5.6 & 4.5 & 6.88 \\
External & 2.6 & 1.8 & 3.0 & 4.2 & 0 & 4.53 \\
Response & 16.7 & 15.5 & 17.2 & 17.2 & 17.9 & 0.37 \\
Negative & 23.4 & $23.9_{\mathrm{a}, \mathrm{b}}$ & $33.6_{\mathrm{b}}$ & $18.1_{\mathrm{a}}$ & $17.9_{\mathrm{a}, \mathrm{b}}$ & $12.24^{* *}$ \\
Self & 0.3 & 0.9 & 0 & 0 & 0 & 3.69 \\
External & 1.9 & 1.8 & 1.5 & 2.8 & 0 & 2.39 \\
Response & 21.5 & $21.7_{\mathrm{a}, \mathrm{b}}$ & $32.1_{\mathrm{b}}$ & $15.8_{\mathrm{a}}$ & $17.9_{\mathrm{a}, \mathrm{b}}$ & $13.54^{* *}$ \\
$N$ Note. Chissuare & 642 & 226 & 134 & 215 & 67 & \\
\hline
\end{tabular}

Note. Chi-square tests were conducted with $d f=3$. Cell entries with different subscripts are significantly different from one another at $p<.05$ based on pairwise comparisons of column proportions using the Bonferroni correction.

$* p<.05 . * * p<.01 . * * * p<.001$. 
Table 4

Framing of Climate Change Impacts and Actions across Leading U.S. Newspapers

\begin{tabular}{l|cccccc}
\hline & Total & NYT & WSJ & WP & USA & Chi-sq. \\
\hline & $\%$ & $\%$ & $\%$ & $\%$ & $\%$ & \\
Impact Frame & & & & & & \\
$\quad$ Environmental & 36.4 & $35.8_{\mathrm{a}}$ & $16.4_{\mathrm{b}}$ & $44.7_{\mathrm{a}}$ & $52.2_{\mathrm{a}}$ & $36.71^{* * *}$ \\
Health & 12.6 & $10.6_{\mathrm{a}, \mathrm{b}, \mathrm{c}}$ & $4.5_{\mathrm{b}}$ & $16.7_{\mathrm{a}, \mathrm{c}}$ & $22.4_{\mathrm{c}}$ & $17.99^{* * *}$ \\
Economic & 7.5 & $7.5_{\mathrm{a}, \mathrm{b}}$ & $3.0_{\mathrm{a}}$ & $7.9_{\mathrm{a}, \mathrm{b}}$ & $14.9_{\mathrm{b}}$ & $9.34^{*}$ \\
$\quad$ Security & 4.4 & 4.0 & 2.2 & 5.6 & 6.0 & 2.71 \\
Action Frame & & & & & & \\
$\quad$ Environmental & 9.7 & 9.3 & 6.0 & 11.6 & 11.9 & 3.48 \\
$\quad$ Health & 3.4 & 3.1 & 1.5 & 5.6 & 1.5 & 5.36 \\
Economic - positive & 15.9 & 13.3 & 20.1 & 16.7 & 13.4 & 3.40 \\
$\quad$ Economic - negative & 20.4 & $18.6_{\mathrm{a}}$ & $35.1 \mathrm{~b}$ & $14.0_{\mathrm{a}}$ & $17.9 \mathrm{a}, \mathrm{b}$ & $23.98^{* * *}$ \\
$\quad$ Security & 7.3 & 8.4 & 9.7 & 4.2 & 9.0 & 4.89 \\
$\quad$ Conflict & 42.2 & $38.1_{\mathrm{a}}$ & $53.0_{\mathrm{b}}$ & $42.3_{\mathrm{a}, \mathrm{b}}$ & $34.3_{\mathrm{a}, \mathrm{b}}$ & $9.69 *$ \\
$\quad$ Accountability & 6.5 & 6.2 & 7.5 & 6.5 & 6.0 & 0.97 \\
$\quad$ Moral - Secular & 6.4 & $4.9 \mathrm{a}, \mathrm{b}, \mathrm{c}$ & $1.5 \mathrm{~b}$ & $9.3_{\mathrm{a}, \mathrm{c}}$ & $11.9 \mathrm{c}$ & $12.76^{* *}$ \\
$\quad$ Moral- Religious & 1.1 & 0.4 & 0.7 & 2.3 & 0 & 4.81 \\
$N$ & 642 & 226 & 134 & 215 & 67 & \\
\hline
\end{tabular}

Note. Chi-square tests were conducted with $d f=3$. Cell entries with different subscripts are significantly different from one another at $p<.05$ based on pairwise comparisons of column proportions using the Bonferroni correction.

$* p<.05 . * * p<.01 . * * * p<.001$. 


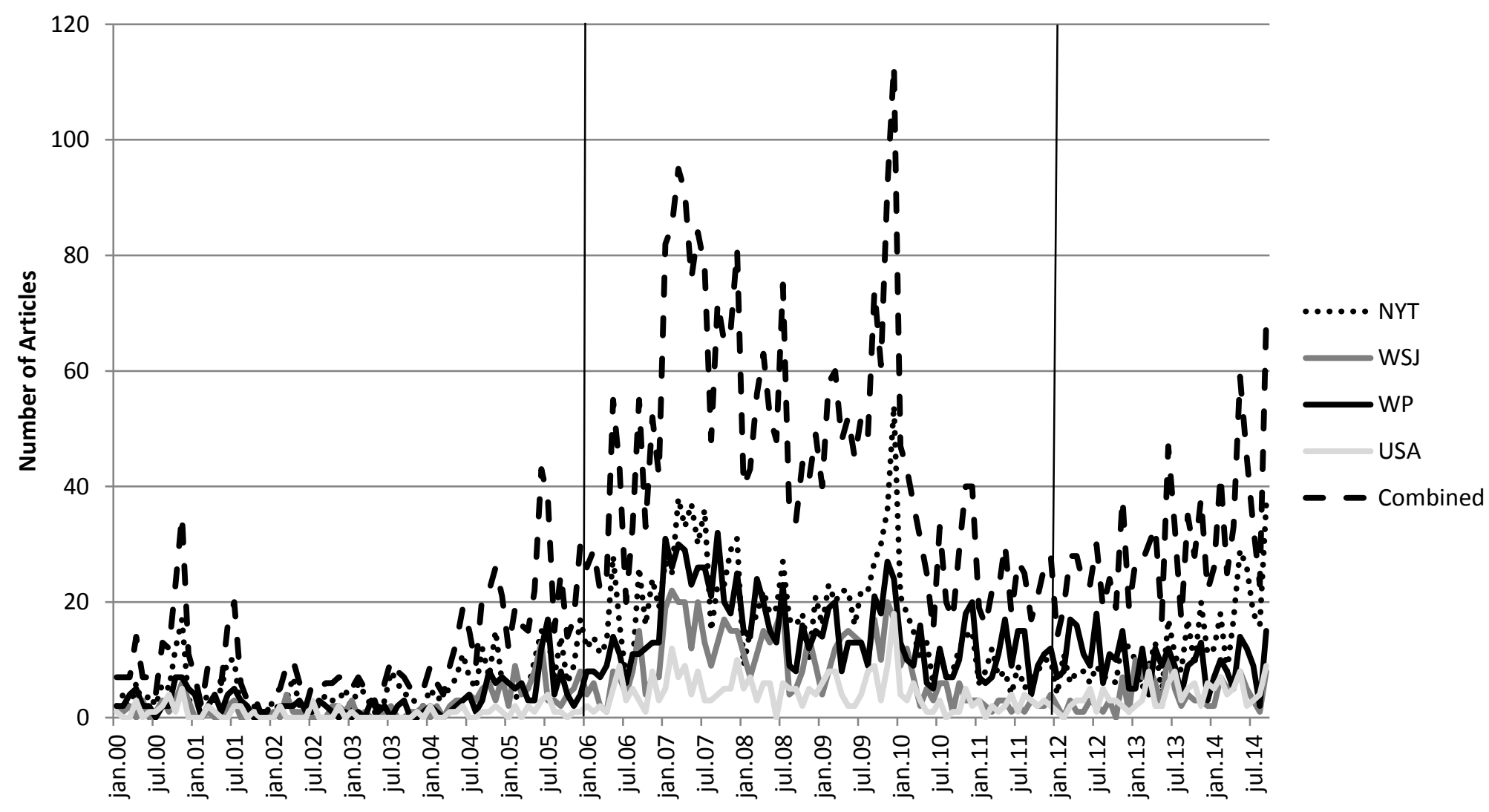

Figure 1. U.S. Newspaper Coverage of Climate Change or Global Warming between January 1, 2000 and September 30,2014 